\title{
Effect to Analyze the Arab Spring for Political Change in the Middle East
}

\author{
Najib Maloud Almarhoon \\ Zawia University, Libiya.
}

\begin{abstract}
This paper applies central social science approaches in order to analyze recent developments in the region - a major task of theoretically oriented social sciences in the coming years. In addition to providing an overview of the existing literature on the Arab Spring, the article examines the empirical results of political diversification in the Arab world. A two - by - two matrix of political rule that differentiates according to the type of rule and the degree of stability is presented and discussed. Although the analysis draws heavily on rent theory, it also applies findings from transition theory and revolution theory to illuminate the current political dynamics in the Middle East. This article deals with the Arab Spring as a process of deep political change in the Arab world, previously the only major world area where authoritarianism persisted unchallenged for decades. While in various countries of the Arab world mass protests in 2011 forced rulers to resign, other authoritarian regimes have - despite political and economic pressure - so far been able to remain in power, or have even been only insignificantly affected.
\end{abstract}

Keywords : Arab Spring, Middle East, rent theory, revolution theory, transition theory, democratization, authoritarianism, political and economic liberalization.

\section{Introduction}

Independently of its outcome, the Arab Spring can be regarded as an event of global historical significance. From its onset in early 2011, it has been understood as a process of political change in the Middle East. The Arab world was the only major area where authoritarian rule could be established region - wide in the twentieth century, and where regimes managed to defy global trends beyond the threshold of the twenty - first century. But in Tunisia and Egypt in 2011, internal mass protests forced the leadership to resign within weeks. Inspired by these successes, popular movements throughout the Middle East were bolstered. They demanded substantial political reform and, in some cases, regime change. After decades of authoritarian rule and political stagnation, popular movements were finally able to destabilize or overthrow a number of authoritarian regimes in the Arab world. In the coming years, one of the main tasks of theoretically oriented social sciences will be to critically follow and explain the Arab Spring. For this purpose, such studies can draw on a wider foundation of social science than one might initially think. The fall of Zine el - Abidine Ben Ali, Hosni Mubarak, and other regime leaders was not predicted by social science, unless the notoriously vague conclusions of academic articles - which state that due to the unsustainable development of the Arab systems, change is inevitable - are accepted as a prognosis. Yet, at the same time, it should be taken into account that making predictions about the nature and timing of social structural change is difficult for objective reasons. The research subjects of the social sciences have, in contrast to those of chemistry or physics, intentions and choices whose occurrence and effects are difficult to identify. The primary role of the social sciences is to explain events and structures. Thus, until the Arab Spring, the task of social scientists was indeed to analyze the causal and intentional background of authoritarian structures' sustainability in the Middle East. At the same time, it can hardly be ignored that the potential of non - Islamist civic movements in the region was underestimated by social scientists. Moreover, it must be mentioned that - in reaction to the "deviant role" of the Arab world - some deterministic approaches and models were established that neglected or even ignored the idea that actors in the Middle East have choices. It would, however, mean throwing the baby out with the bath water if - because of the apparent failure of deterministic approaches - it were concluded that, in general, social scientific approaches have no value in the analysis of the Arab Spring. Reliable social science research, including humanities work analyzing the Middle East before the Arab Spring, works on the basis of the ceteris paribus clause: Statements that specific events and structures develop certain effects are made with the restriction that it applies only if other things are equal. The statement "smoking kills" is not false just because many smokers do not die from the immediate consequences of smoking, or even because nonsmokers also die. The same applies to social scientific approaches to the Middle East - they are not invalid just because they did not anticipate the Arab Spring. The aim of this paper is to outline methods that use central social scientific approaches to analyze the Arab Spring. Thus, the paper attempts to contribute to the explanation and description of political change in the Middle East with reference to 
relevant social science theories. As the subject of the essay is very much in flux, it must be conceded that the present article has a strong exploratory character.

\section{OBJECTIVE}

(i) To providing an overview of the existing literature on the Arab Spring, the article examines the empirical results of political diversification in the Arab world.

(ii) To analyze recent developments in the region - a major task of theoretically oriented social sciences in the coming years.

\subsection{Demographic Change}

III. Arab Spring

A first approach to the Arab Spring argues that change was inevitable because of the critical socioeconomic development in the authoritarian states of the Middle East. According to Volker Perthes (2011: 24), the most important trigger for this change was the demographic development of the Arab world. From 1970 to 2010, the population nearly tripled, going from 128 million to 359 million inhabitants (Hegasy 2011: 41). An estimated 41 percent of these people live below the poverty line (UNDP 2009: 22), and nearly 30 percent of the population is between the ages of 20 and 35 (Perthes 2011: 30). Although the current generation is better educated and qualified than the previous one - due to a strengthened education sector and increased networking through digital technology - many are unable to find employment (ibid.: 30-31). The unemployment rate for the population cohort between the ages of 15 and 24 was 25.6 percent in 2003, the highest in the world (ILO 2004: 1, 8; UNDP 2009: 20). Additionally, the labor market offers limited opportunities for university graduates (Perthes 2011: 31). The consequent lack of prospects, rising costs of living, and anger over obviously corrupt and repressive rulers compelled this generation rise up against the authoritarian regimes

\subsection{Social Media}

Another view, held especially by Philip Howard and Muzammil Hussain (2011), attributes the outbreak of the Arab Spring to the access to digital media, including social media such as Facebook, Twitter, YouTube, and text messages. Advocates of this approach make clear that the dissent between regimes and populations already existed long before the spread of the Internet. However, virtual communication gave people an instrument that made it possible for them to share their resentment with like - minded people and to organize movements against authoritarian rulers (ibid.: 36-37, 41). Even before the outbreak of the riots, the strongest criticism came from political bloggers: investigative journalism in the Middle East has long been the domain of private actors (ibid.: 36,42 ). The Internet showed videos which presented the corrupt rulers' luxurious standard of living, thereby substantiating the once abstract criticism of the regimes (ibid.: 36). Furthermore, digital media displayed the freedom and prosperity of people in the West and elsewhere in the world. Every day more people in the Arab world were exposed to the rest of the world through international online news or the use of programs like Skype to talk with friends or relatives living abroad (see Howard and Hussain 2011: 36, 42). The increasingly multilayered access to media gave people the opportunity to question political norms and values often leading to a democratic orientation. After Mohammad Bouazizi's legendary self - immolation, people communicated throughout Tunisia in various online forums, expressing their solidarity as well as their dissatisfaction with the political situation in the country. Social media offered a space for solidarity that was ultimately transferred from the virtual world to the real one and manifested in mass protests against the authoritarian regime (ibid.: 36-38). Messages and posts on Facebook and Twitter or simple text messages immediately informed protestors about the next step of action and the location where it would take place. Within a few weeks, guided instructions for organizing successful protests were circulated on the Internet (ibid.: 3840). Authentic videos and pictures taken by protesters with cameras on mobile phones inspired citizens of other Arab states to organize protests - some of which were the largest in decades (ibid.: 38, 43). Abroad, social media platforms were used as channels to support protestors, to express solidarity, and to encourage people in their chosen path; for instance, external supporters programmed software that enabled activists to circumvent government firewalls (ibid.: 37,44 ).

\section{Economic Liberalization}

From a political - economic point of view, the Arab Spring was caused by a fundamental crisis of the authoritarian social contract. The contract had regulated relations between the people of the Arab world and the power systems for decades (Harders 2011). This authoritarian bargain implicitly promised the population a minimum of subsidies. In exchange, people preserved some degree of political loyalty to the regime. If this minimum economic safety net guaranteed by the state were no longer maintained, the regime would suffer from a deficit of legitimacy and the authoritarian bargain would collapse (Desai et al. 2011). However, the timing of the Arab Spring still cannot be explained, as the crises that led to the failure of the Middle Eastern authoritarian 
bargain in 2011 had existed for years, if not decades (Beck 2010). One result of the regional oil boom in the 1970s was the establishment of the rent - based system of "petrolism" in the Middle East. Rents are incomes which are not balanced by labor and capital, and are thus at the free disposal of the recipients. In the 1970s, not only did the incomes generated by rents of the oil - producing states in the Middle East escalate, but, through politically motivated transfers from the Arab oil states to the oil - poor countries of the region, political entire states also emerged (Beck 2009). Because of falling oil prices, the system of petrolism fell into crisis during the last two decades of the twentieth century. The regimes of the Middle East reacted with a relatively complex, but unsustainable, attempt at crisis management, adopting limited economic reforms mostly aimed at enforcing foreign trade (Fürtig 2007; Richter 2011). At different stages most countries initiated political liberalization, but then withdrew from it in deliberalization phases (Kienle 2001). The structural dependence on rents, however, was not overcome. Two of the entire system's typical defects appeared (although this still does not explain the exact timing of the Arab Spring): First, the distribution - oriented strategy of the entire country eventually meets its limits. The productive sectors are neglected and government spending expands (especially with high population growth), while chances to generate compensating income through taxes are limited due to the neglected productive potential. Second, the primacy of the distributional policy is intended to depoliticize society. Therefore, the development of political institutions is neglected in entire states. Again, this cannot explain the outbreak of the Arab Spring, but it makes it plausible that once the regimes in the Middle East were confronted with a powerful opposition movement, they did not have the appropriate means to drive those movements on system - compatible paths (Beck 2009, 2011a).

\section{Political Diversification of the Arab World Caused by the Arab}

The Arab Spring disrupted the high degree of homogeneity among stable authoritarian regimes in the Middle East. This means, first, that there are some countries where authoritarian structures have been shaken to the point that one can speak of transition states. A central finding of transition theory is that transition has to be seen as an open process (Carothers 2002). While most transition processes after the collapse of the totalitarian regimes in Europe were affected by the global "spirit of democracy" (Mahatma Gandhi), they did not always result in the establishment of democratic systems. Rather, in many cases hybrid systems or new types of authoritarian systems developed. Regional examples from the Middle East are the authoritarian Islamic Republic of Iran, which emerged from the 1979 revolution, and the political system of Turkey, which developed after the failure of Kemalism in 1950 - and went through a process of democratization over decades (Diamond 2002: 31). Second, certainly not all authoritarian regimes in the Arab world have been disrupted by the Arab Spring. Although no country has escaped the regional debate about the Arab

Spring, the ruling houses of some regimes - especially in the Gulf states - have so far known how to keep the foundations of their authoritarian rule intact. Third, there are strong indications that two regime types have been created which have more than short - term potential. On the one hand, not all protest movements in the Arab world have succeeded in forcing the ruling regime into transformation by peaceful means. Some regimes still control - at least temporarily - the levers of power with the help of their repressive apparatuses, yet they have been unable to force the newly formed opposition movements to their knees. A prime example is Syria. On the other hand, transition countries can differ, as the transition process can be regarded as stable or unstable. It should be noted that transition processes are sui generis dynamic, and only in exceptional cases come to pass without retarding moments and setbacks. Although it may be controversial in a particular case, it is still possible to distinguish systematically between transitions showing a trend away from authoritarianism toward a new system and cases where the old system is strong enough to reintroduce authoritarianism. It may also be possible that newly emerged political players favor an authoritarian regime. The consequences of the latter could lead to the perpetuation of the old regime, to an authoritarian pact between old and new authoritarian elites, or to the takeover of state power by new authoritarian elites. The result is a new two - by - two matrix of political rule in the Middle East generated by the Arab Spring. Saudi Arabia, Syria, Tunisia, and Egypt come close to ideal types, although to varying degrees.

\section{Stable Authoritarian Systems: The Case of Saudi Arabia}

\section{Four Types of Political Rule}

Of those states in the Middle East which fall under the category of stable authoritarian, the Kingdom of Saudi Arabia is regionally and globally the most important regime. To date, the Saudi regime has succeeded in keeping its authoritarian rule stable without implementing substantial liberalization measures. When the Arab Spring began, various observers expected certain change in Saudi Arabia (Lacroix 2011: 48). This view appeared plausible, as Saudi Arabia shows similar grievances to those Arab systems that faced massive protests: high unemployment, especially among the young; extreme corruption; political repression; and a wide social gap between the establishment and the young population (ibid.). Occasional protests occurred at the beginning 
of 2011, particularly in the Shiite east of the country (Freitag 2011: 23). But the regime succeeded in using its extensive material resources to stabilize the country (Lacroix 2011: 53). The revenues from the oil sector allowed the monarchy to maintain a policy of "sticks and carrots": concessions helped to depoliticize strategic sectors of society, and at the same time, rents were used to finance an all - encompassing security and intelligence directorate (see Lacroix 2011: 53). When civil unrest occurred in other Arab states, the government imposed a nationwide ban on demonstrations and increased the contingent of security forces. King Abdullah also announced a subsidy program of 130 billion USD (Steinberg 2011). Furthermore, the royal family received support from the influential Council of Senior Islamic Scholars (Hai'at Kibar al - Ulama), which said that demonstrations are not compatible with Islam and therefore declared a ban on protests to be religiously lawful

\section{(ii) Unstable Authoritarian Systems: The Case of Syria}

Although the Syrian opposition had already expressed its discontent with the authoritarian system in the past (for example, the "Damascus Declaration" in 2005), the regime led by Basharal - Assad had succeeded on previous occasions at stifling major protests and maintaining its stability. In the wake of the Arab Spring, there was massive mobilization by the opposition, which the regime tried unsuccessfully to contain through cosmetic reforms and massive repression. At the same time, however, the regime was able to control the state institutions.

Thus, a civil war-like standoff has resulted. At the time of the writing, it is not predictable how long this situation will last, if the Assad regime will maintain stable authoritarian rule, or if the conflict will lead to regime collapse and a progressive political transformation in Syria (Beck and Hüser 2011).

\section{Stable Systems of Transition: The Case of Tunisia}

Within one month, protestors in Tunisia overthrew a decades - old authoritarian regime. After 23 years as president, Ben Ali was forced to resign in late January 2011. Subsequent developments created a promising political atmosphere for the Constituent Assembly election in October 2011, and the newly elected assembly was tasked with drafting a new constitution and appointing a new government. Apart from protests in February 2011, which called for the dismissal of Ben Ali's supporters in government positions, there have been no destabilizing demonstrations or police suppression (Schraeder and Redissi 2011: 1, 14-17). Compared to other countries in the region, Tunisia has good prerequisites for democratization (Asseburg and Werenfels 2011: 8); thus it can be considered a stable transformation country.

\section{(iii) Unstable Transition Systems: The Case of Egypt}

Similarly to Tunisia, Egypt has been in transition since the resignation of President Hosni Mubarak in February 2011. Egypt's transition, however, appears to be less consolidated than that of Tunisia. Since the fall of 2011, the country has been shaken by massive riots, and the state's reactions have led to substantial political and economic instability. The riots have been primarily directed against the transitional military government, which has delayed or blocked the transition of power to a civilian government. The "military - industrial complex" (Davis 2011b) has steadily expanded its political and economic role ever since its emergence in 1954. This suggests that despite the resignation of Mubarak, the regime's forces are still strong. Many observers state that the crucial factor blocking a democratic transformation is - presently - not the strength of Islamist groups but the military's interference (Davis 2011b, c). But there are also other assessments: In the post - Mubarak parliamentary elections, Islamist parties won two - thirds of the seats, stoking fears of an undemocratic Islamization of the political system. The rising popularity of Salafism, and the possibility of a coalition between Salafists and the Muslim Brotherhood, is perceived as threatening (Ashour 2012).

\section{Conclusion}

Theory - based social science research on the Middle East has a strong incentive to analyze the Arab Spring and the changing empirical realities of Middle Eastern politics. This paper has attempted to contribute to this objective by presenting and discussing political change in the Middle East on the basis of a two - by - two matrix of political rule that differentiates according to the type of rule and the degree of stability. Based on a discussion of several case studies, the paper has shown on the one hand that this matrix helps to arrange the observed diversification of Arab regimes. On the other hand, it has shown that the matrix contributes to comprehending the dynamics of political change in the Middle East, a research topic that is still in flux. After an exploratory summary of explanations for the Arab Spring in general, the paper has used three theoretical strands of the social sciences - rent theory, transition theory, and revolution theory - to make an explanatory contribution as to why the regimes in the Arab world have diversified, and to discuss the implications. Thereby, the rent theory approach has proven to be particularly fruitful, especially because it can explain the fundamental difference between the regimes shaken by the Arab Spring and the persistently stable regimes in the Arab world. 
Transition theory and revolution theory help to describe the complex, and sometimes contradictory, developments in the Middle Eastern countries - particularly in those that have been strongly affected by the Arab Spring.

\section{References}

[1]. Agence France-Presse(2011), Jordan Defers Corruption Bill Debate After Outcry, 29 September, online: <www.google.com/hostednews/afp/article/ALeqM5gdA - G4PSTljqlfmQTmBbcnGb8nMg?docId=CNG.92682db4ef0a99a08f363a 03e200e9e7.61> (13 December 2011).

[2]. American University of Beirut and Konrad Adenauer Stiftung (eds) (2012), The Arab Uprisings -What Happened, What's Next?, Lecture and Working Paper Series, 1, Special Issue, Beirut:American University of Beirut.

[3]. Arbeitsstelle Politik des Vorderen Orients (eds) (2011), Proteste, Revolutionen, Transformationen -die Arabische Welt im Umbruch, Berlin: Freie Universität Berlin, Center for Middle Easternand North African Studies, July, online: $<$ www.polsoz.fu - berlin.de/polwiss/forschung/

[4]. international/vorderer - orient/publikation/WP_serie/WP1_All_FINAL_web.pdf $>$ (28 February (2012).

[5]. Asda'a Burson-Marsteller (2011), 3rd Annual Asda'a Burson-Marsteller Youth Study, March, online: <www.arabyouthsurvey.com/2010/files/AYS_2010_white_paper.pdf> (22 April 2012).

[6]. Ashour, Omar (2012), Egypt's Salafi Challenge, Washington: Brookings Institute, 3 January, online: $<$ www.brookings.edu/opinions/2012/0103_salafis_ashour.aspx > (10 January 2012).

[7]. Asseburg, Muriel (2011a), Zur Anatomie der Arabischen Proteste und Aufstände, in: Aus Politikund Zeitgeschichte, 61, 39 , 3-8.

[8]. Asseburg, Muriel (ed.) (2011b), Proteste, Aufstände und Regimewandel in der Arabischen Welt -Akteure, Herausforderungen, Implikationenund andlungsoptionen, Berlin: Stiftung Wissenschaft und Politik, online: <www.swp - berlin.org/fileadmin/contents/products/studien/2011_S27_ass_ks.pdf> (2 December 2011).

[9]. Asseburg, Muriel, and Isabelle Werenfels (2011c), Tunesien - Einzelfall oder Dominostein? Vergleichbare

[10]. Probleme - Unterschiedliche Rahmenbedingungen, Berlin: Stiftung Wissenschaft and Politik, 4 January, online: <www.swp - berlin.org/de/publikationen/swp - studien - de/swp - studien - detail/article/tunesien_einzelfall_oder_trend.html > (15 December 2011).

[11]. Bank, André (2011), Jordanien und Marokko: Lösungsweg Verfassungsreform?, in: Muriel Asseburg (ed.), Proteste, Aufstände und Regimewandel in der Arabischen Welt-Akteure, Herausforderungen, Implikationen und Handlungsoptionen, Berlin: Stiftung Wissenschaft and Politik, 30-32, online: <www.swp - berlin.org/fileadmin/contents/products/studien/2011_S27_ass_ks.pdf> (2 December 2011).

[12]. Barany, Zoltan (2011), The Role of the Military, in: Journal of Democracy, 22, 4, 24-35.

[13]. Basedau, Matthias, and Robert Kappel (eds) (2011), Machtquelle Erdöl. Die Außen-, Innen- und Wirtschaftspolitik von Erdölstaaten, Baden - Baden: Nomos Verlag.

[14]. Beblawi, Hazem, and Giacomo Luciani (1987), The Rentier State, London: Croom Helm.

[15]. Beck, Martin (2011a), Machtquelle Erdöl. Ein Theoriegeleitetes Analyseraster, in: Matthias Basedau and Robert Kappel (eds), Machtquelle Erdöl. Die Außen-, Innen- und Wirtschaftspolitik von Erdölstaaten, Baden - Baden: Nomos Verlag, 13-35.

[16]. Beck, Martin (2011b), Ein Strukturproblem, in: The European, 14February,online: $<$ www.theeuropean.de/martin - beck/5688 - politische - zusammenarbeit> (16 February 2011).

[17]. Beck, Martin (2010), The Middle East as a Crisis Region, in: Miriam Dunn Cavelty and Victor

[18]. Mauer (eds) (2010), The Routledge Handbook of Security Studies, London: Routledge, 309-318.

[19]. Beck, Martin (2009), Rente und Rentierstaat im Nahen Osten, in: Martin Beck, Cilja Harders, Annette Jünemann and Stephan Stetter (eds), Der Nahe Osten im Umbruch. Zwischen Transformationund Autoritarismus, Wiesbaden: VS Verlag für Sozialwissenschaften, 25-49.

[20]. Beck, Martin (2007a), Paving the Way for Democracies or Strengthening Authoritarianism?Reforms in the Middle East, in: Henner Fürtig (ed.), The Arab Authoritarian Regime between Reform and Persistance, Newcastle: Cambridge Scholars Press, 1-24.

[21]. Beck, Martin (2007b), Der Rentierstaats - Ansatz und das Problem abweichender Fälle, in: Zeitschriftfür Internationale Beziehungen, 14, 1, 43-70.

[22]. Beck, Martin, and Lea Collet (2010), Das Jordanische Wahlgesetz 2010: Demokratisierung oder Stagnation?, November,online: <www.kas.de/wf/doc/kas_20947 - 1522 - 1 - 30.pdf?101108 101327> (2 December 2010).

[23]. Beck, Martin, Cilja Harders, Annette Jünemann and Stephan Stetter (eds) (2009), Der Nahe Ostenim Umbruch. Zwischen Transformation und Autoritarismus, Wiesbaden: VS Verlag für Sozialwissenschaften.

[24]. Beck, Martin, and Simone Hüser (2011), Syrien und der Arabische Frühling - Über die Lage and Zukunft des Regimes Baschar Al-Assads, online: <www.kas.de/wf/doc/kas_29527 - 1522 - 1 - 30.pdf?111128104248> (28 November 2011).

[25]. Belakhdar, Naoual (2011), „Wir hatten im Oktober 1988 unsere Revolution“. Eine Analyse der Gescheiterten Protestbewegung in Algerien 2011, in: Arbeitsstelle Politik des Vorderen Orients (eds), Proteste, Revolutionen, Transformationen - die Arabische Welt im Umbruch, Berlin: Freie Universität Berlin, Center for Middle Eastern and North African Studies, July,82-91, online: <www.polsoz.fu - berlin.de/polwiss/forschung/international/vorderer - orient/publikation/WP_serie/WP1_All_FINAL_web.pdf $>$ (2 December 2011).

[26]. Benchemsi, Ahmed (2012), Morocco: Outfoxing the Opposition, in: Journal of Democracy, 23, 1,57-69.

[27]. Byman, Daniel (2011), After the Hope of the Arab Spring, the Chill of an Arab Winter, in: The Washington Post,2December,online: <www.washingtonpost.com/opinions/after - the - hopeof - the - arab - spring - the - chill - of - an - arab - winter/2011/11/28/gI QABGqHIO_story.html> (15 December

[28]. 2011)

[29]. Carlstrom, Gregg (2011), Jordan's King Appoints Reform - MindedCabinet,in:AlJazeera, 25October,online: $<$ www.aljazeera.com/news/middleeast/2011/10/201110247497211541.html $>(25$ October 2011).

[30]. Carothers, Thomas (2002), The End of the Transition Paradigm, in: Journal of Democracy, 13, 1,5-21.

[31]. Committee to Protect Journalists (2011), Jordan's Anti-Corruption Bill Would Restrict Press,30 September, online: $<$ www.cpj.org/2011/09/jordans - pending - anti - corruption - law - willrestrict.php> (30 September 2011).

[32]. Cunningham, Finian (2012), Saudi Arabia: House of Saud, Falling House of Cards, in: Global Researcher, 23 March,online: $<$ http://globalresearch.ca/index.php? context=va\&aid=29934>(24 March 2012). 
[33]. Davis, Eric (2011a), Making Sense of the Arab Spring (Part 1), in: New Middle East,22 November, online: $<$ http://new - middle - east.blogspot.com/2011/11/making - sense - ofarab - spring - part - 1.html $>$ (20 December 2011).

[34]. Davis, Eric (2011b), Making Sense of the Arab Spring (Part 2), in: New Middle East, 22 November, online: $<\mathrm{http} / / /$ new - middle - east.blogspot.com/2011/11/making - sense - of - arabspring - part - 2.html $>$ (20 December 2011).

[35]. Davis, Eric (2011c), Making Sense of the Arab Spring (Part 3). Egypt's Stalled Democracy, in: New Middle East,30December,online: <http:/new - middle - east.blogspot.com/2011/12/making - sense - of - arab - spring - part - 3.html > (10 January 2012).

[36]. Desai, Raj M., Anders Olofsgard and Tarik Yousef (2011), Is the Arab Authoritarian Bargain Collapsing?,

[37]. BrookingsInstitution,9February,online: <www.brookings.edu/opinions/2011/0209_arab_economies_desai_yousef.aspx> February 2012).

[38]. Diamond, Larry J. (2002), Thinking about Hybrid Regimes, in: Journal of Democracy, 13, 2, 21-35.Dugulin, Riccardo (2012), Human Rights and Syria: An Original Position for the Gulf,26 March, online: $<$ http://arabsthink.com/2012/03/26/human - rights - and - syria - an - originalposition - for - the - gulf/> (2 April 2012).

[39]. Dunn Cavelty, Miriam, and Victor Mauer (eds) (2010), The Routledge Handbook of Security Studies,London: Routledge.

[40]. EU (European Union) (2007), Arabische Republik Syrien. Länderstrategiepapier 2007-2013 und Nationales

[41]. Richtprogramm2007-2010,online: $<$ http://ec.europa.eu/world/enp/pdf/country/enpi_csp_nip_syria_de.pdf $>$ (13 February 2012).

[42]. Freitag, Ulrike (2011), Saudi - Arabien: Erkaufte Stabilisierung,in:MurielAsseburg(ed.), Proteste,Aufstände und Regimewandel in der Arabischen Welt - Akteure, Herausforderungen,Implikationenund andlungsoptionen, Berlin: Stiftung Wissenschaft und Politik, 23-26,

[43]. Furceri, Davide (2012), Unemployment and Labor Market Issues in Algeria, IMF Working Paper,99, nline: $<$ www.imf.org/external/pubs/ft/wp/2012/wp1299.pdf> (3 May 2012).

[44]. Fürtig, Henner (ed.) (2007), The Arab Authoritarian Regime between Reform and Persistance, Newcastle:

[45]. Cambridge Scholars Press.

[46]. Hamid, Shadi, and Courtney Freer (2011), How Stable is Jordan? King Abdullah's Half-HeartedReforms and the Challenge of the Arab Spring, online:

[47]. <www.brookings.edu/research/papers/2011/11/jordan - hamid - freer> (2 April 2012).

[48]. Harders, Cilja (2011), Die Umbrüche in der Arabischen Welt: Zwischen Revolution und Restauration, in: Arbeitsstelle Politik des Vorderen Orients (eds), Proteste, Revolutionen, Transformationen- die Arabische Welt im Umbruch, Berlin: Freie Universität Berlin, Center for Middle Eastern and North African Studies, 10-37, online: $<$ www.polsoz.fu - berlin.de/polwiss/forschung/international/vorderer - orient/publikation/WP_serie/WP1_All_FINAL_web.pdf $>(2$ December 2011).

[49]. Hattar, Musa (2011), A Man Dies, 130 Injured in Jordan Clashes, in: Agence France-Presse, 25 March, online: $<$ www.google.com/hostednews/afp/article/ALeqM5j4r9jj65akTGKygpx 0PMsQVHITg?docId=CNG.bd4326a710> (18 October 2011).

[50]. Hazaimeh, Hani (2011), Journalists, Advocates Fear for Press Freedoms, in: Jordan Times,28 September, online: $<$ http://jordantimes.com/journalists - advocates - fear - for - press - freedoms $>(2$ October 2011).

[51]. Hegasy, Sonja (2011), „Arabs Got Talent“: Populärkultur als Ausdruck gesellschaftlicher Veränderungen,in: Aus Politik und Zeitgeschichte, 61, 39, 40-45.

[52]. Heibach, Jens (2011), Der Anfang vom Ende? Der Jemen nach Ali 'Abdullah Salih, in: Arbeitsstelle Politik des Vorderen Orients (eds), Proteste, Revolutionen, Trans-formationen - die arabische Welt im Umbruch, Berlin: Freie Universität Berlin, Center for Middle Eastern and North African Studies, 130-146, online: <www.polsoz.fu - berlin.de/polwiss/for - schung/international/vorderer - orient/publikation/WP_serie/WP1_All_FINAL_web.pdfs (2 December2011).

[53]. Henry, Clement M. (2011), Countries at the Crossroads 2011: Tunisia, in: Freedom House,

[54]. online:<www.freedomhouse.org/sites/default/files/inline_images/TUNISIAfinal.pdf> (8 May 2011).

[55]. Hoffmann, Anja (2011), Wem gehört der marokkanische Wandel? Eine Analyse des umkämpften politischen Felds in Marokko, in: Arbeitsstelle Politik des Vorderen Orients

[56]. (eds), Protests, Revolutions and Transformations - the Arab World in a Period of Upheaval, Working Paper, 1, 92-109.

[57]. Howard, Marc M. (2011), Similarities and Differences between Eastern Europe in 1989 and the Middle East in 2011, in: The Monkey Cage Blog, $30 \quad$ May, $<$ http://themonkeycage.org/blog/2011/05/30/similarities - and - differences - between - eastern - europe - in - 1989 - and - themi ddle - east - in - 2011/> (31 May 2012).

[58]. Howard, Philip N., and Muzammil M. Hussain (2011), The Role of Digital Media, in: Journal of Democracy, 22, 3, 35-48.

[59]. HRW (Human Rights Watch) (2012), Voices from Tahrir: Bread, Freedom, Dignity, 25 January, online: $<$ www.hrw.org/audio/2012/01/25/voices - tahrir - bread - freedom - dignity > (7 February 2012).

[60]. Huntington, Samuel P. (1991), The Third Wave: Democratization in the Late Twentieth Century, Norman: University of Oklahoma Press.

[61]. ICG (International Crisis Group) (2012), Dallying with Reform in a Divided Jordan, 12 January, online: <www.crisisgroup.org/en/publication - type/media - releases/2012/mena/dallyingwith - reform - in - a - divided - jordan.aspx> (12 January 2012).

[62]. ILO (International Labour Office) (2004), Global Employment Trend for Youth 2004, August, online: <www.ilo.org/wcmsp5/groups/public/@ed_emp/@emp_elm/@trends/documents/publication/wcms_114351.pdf> (2 October 2011).

[63]. IMF (International Monetary Fund) (2012a), IMF Executive Board Concludes 2011 Article IV Consultation

[64]. with Qatar, 31 January, online:

[65]. <www.imf.org/external/np/sec/pn/2012/pn1207.htm> (4 March 2012)

[66]. IMF (International Monetary Fund) (2012b), Qatar 2012 Article IV Consultation. IMF Country Report 2012, 18 January, online: www.imf.org/external/pubs/ft/scr/2012/cr1218.pdf (7 February 2012).

[67]. IMF (International Monetary Fund) (2011a), Algeria Should Reduce Reliance on Oil, Create More Jobs, Says IMF, 26 January, online:<www.imf.org/external/ pubs/ft/survey/so/2011/int 012611a.htm> (29 January 2012).

[68]. IMF (International Monetary Fund) (2011b), Middle East and North Africa: Economic Outlook and Key Challenges, 10 September, online: <www.imf.org/ external/region/mcd/deauville/note 091011.pdf> (4 October 2011). 
[69]. IMF (International Monetary Fund) (2010), Arab Republic of Egypt: 2010 Article IV Consultation -Staff Report. Public Information Notice on the Executive Board Discussion and Statement by the Executive Director for the Arab Republic of Egypt, April, online: <www.imf.org/external/pubs/ft/scr/2010/cr1094.pdf> (19 September 2011).

[70]. N. Koochakzadeh, V. Garousi, A Tester-Assisted Achy, Lahcen (2009), The Maghreb and the Global Economic Crisis: When Does the Tunnel End?, in: Carnegie Endowment, 17September,online: $<$ www.carnegieendowment.org/2009/09/17/maghreb - and - global - economic - crisis - when - does - tunnel - end/oox > April 2012). 